\title{
Bionomy of Anicla mahalpa Schaus, 1898 (Lepidoptera: Noctuidae: Noctuinae), in the laboratory
}

\author{
Specht, A. a, ${ }^{\mathrm{a} *}$, Formentini, $A C .^{\mathrm{a}}$ and Corseuil, E. ${ }^{\mathrm{c}}$ \\ aLaboratório de Biologia, Departamento de Ciências Exatas e da Natureza, Bloco a, \\ Campus Universitário da Região dos Vinhedos, Universidade de Caxias do Sul - UCS, \\ Alameda João Dal Sasso, 800, Bairro Universitário, CP 32, CEP 95700-000, Bento Gonçalves, RS, Brazil \\ 'Instituto de Biotecnologia, Universidade de Caxias do Sul - UCS, \\ Rua Francisco Getúlio Vargas, 1130, CEP 95070-560, Caxias do Sul, RS, Brazil \\ 'Laboratório de Entomologia, Faculdade de Biociências, Pontifícia Universidade do Rio Grande do Sul - PUCRS, \\ CP 1429, CEP 90619-900, Porto Alegre, RS, Brazil \\ *e-mail: aspecht@ucs.br \\ Received August 21, 2006 - Accepted May 4, 2007 - Distributed May 31, 2008 \\ (With 2 figures)
}

\begin{abstract}
The genus Anicla Grote, 1874 is composed of eleven species; their larvae are harmful, mainly to native and cultivated grasses, but up to now, there is information available of only two species. This study aims at detailing the bionomy of A. mahalpa Schaus; the data were obtained from a laboratory rearing under the following settings: $20 \pm 2{ }^{\circ} \mathrm{C}, 70 \pm 10 \%$ relative humidity and 12 hours of photoperiod. Larvae were fed on ryegrass, Lolium multiflorum Lam. (Poaceae). The results expressed by the mean and respective standard error for the periods of each phase, in days, were the following: egg $6.00 \pm 0.00$, larva $36.47 \pm 0.44$, pre-pupa $5.23 \pm 0.21$, pupa $23.60 \pm 0.37$, and adult: longevity $15.24 \pm 0.75$ with pre-egg-laying-periods of $5.29 \pm 0.32$; egg-laying period, $9.64 \pm 0.81$, and post-egg-laying period, $0.71 \pm 0.27$ days. The mean number of egg-laying cycles per female was $7.36 \pm 0.20$ and 2,014.21 \pm 78.93 eggs per female. Eggs, which are subspheric, have a diameter of $0.76 \pm 0.01 \mathrm{~mm}$; larvae passed through six instars; their head capsules width, provided a mean ratio of growth of 1.482. Pupae presented a mean width and length of $6.07 \pm 0.06$ and $17.24 \pm 0.19 \mathrm{~mm}$, respectively and weight of $0.33 \pm 0.01 \mathrm{~g}$.
\end{abstract}

Keywords: agricultural importance, caterpillar, development, insecta.

\section{Bionomia de Anicla mahalpa Schaus, 1898 (Lepidoptera: Noctuidae: Noctuinae), em laboratório}

\section{Resumo}

O gênero Anicla Grote, 1874 é composto por onze espécies cujas lagartas são nocivas principalmente a gramíneas nativas e cultivadas, entretanto, até o momento só existem informações a respeito de duas espécies. Este estudo objetivou detalhar a bionomia de A. mahalpa Schaus cujos dados foram obtidos a partir de uma criação laboratorial feita sob condições de $20 \pm 2{ }^{\circ} \mathrm{C}, 70 \pm 10 \%$ UR e 12 horas de fotofase. As lagartas foram alimentadas com azevém, Lolium multiflorum Lam. (Poaceae). Os resultados expressos pela média e pelo respectivo erro-padrão para os períodos de cada fase, em dias, foram: ovo $6,00 \pm 0,00$; larva $36,47 \pm 0,44$; pré-pupa $5,23 \pm 0,21$; pupa $23,60 \pm 0,37$ e adulta: longevidade 15,24 \pm 0,75 com períodos de pré-oviposição $5,29 \pm 0,32$; oviposição $9,64 \pm 0,81$ e pós-oviposição $0,71 \pm 0,27$ dias. O número médio de posturas por fêmea foi 7,36 $\pm 0,20$ e de ovos por fêmea, $2.014,21 \pm 78,93$. Os ovos, de formato subesférico, apresentam diâmetro de $0,76 \pm 0,01 \mathrm{~mm}$; as lagartas passaram por seis ínstares cujas médias da largura das cápsulas cefálicas proporcionaram razão média de crescimento de 1,482. As pupas apresentaram em média largura e comprimento $6,07 \pm 0,06$ e 17,24 $\pm 0,19 \mathrm{~mm}$, respectivamente, e peso de $0,33 \pm 0,01 \mathrm{~g}$.

Palavras-chave: desenvolvimento, insecta, importância agrícola, lagarta.

\section{Introduction}

Noctuidae, which account for 24.801 described species, comprehend the most diverse family of macrolepidoptera (Heppner, 1991), and include the biggest number of economically important species, commonly known as armyworms, cutworms, semiloopers and velvetbean caterpillars (Holloway et al., 1992; Scoble, 1995). Specimens of the Noctuinae subfamily are characterized by underground habits, voracious feeding, and the use 
of several host plants (Holloway et al., 1992; Scoble, 1995). Larvae of Anicla Grote, 1874, however rest on their host plants, which are mainly grasses (Foerster and Mello, 1996; Teston et al., 2001). This genus has eleven species (Poole, 1989), but biological knowledge is restricted to two species (Foerster and Mello, 1996; Angulo and Olivares, 1997; Teston et al., 2001).

Among the species found in the south region of Brazil, there is the Anicla mahalpa Schaus, 1898, described from specimen from Castro, Paraná, Brazil (Poole, 1989). It was considered as a synonym of Anicla infecta (Ochsenheimer, 1816) from Hampson (1903); however, Poole (1989) revalidated its specific identity. Considering that knowledge about this species is restricted to the morphology of adults (Schaus, 1898) and recordings of occurrences (Biezanko and Bertholdi, 1951), this study aims at detailing the bionomy of A. mahalpa in the laboratory.

\section{Material and Methods}

Data were obtained in laboratory under $20 \pm 2{ }^{\circ} \mathrm{C}$, $70 \pm 10 \%$ relative humidity, and 12 hours of photoperiod, in the Laboratório de Biologia do Campus Universitário da Região dos Vinhedos, Universidade de Caxias do Sul, Bento Gonçalves, RS, Brasil.

During the adult period, 14 mating pairs were maintained in cylindrical PVC containers of $10 \mathrm{~cm}$ of diameter, and $20 \mathrm{~cm}$ in height. Each container was internally covered with moist filter paper. They were fed on a water solution of honey at $10 \%$ on an absorbent cotton wad, which was changed daily. During the adult period, longevity, oviposition period, including pre and post oviposition, number of events of oviposition and the total number of eggs per female were examined. The preoviposition period is equivalent to the number of days required for females to start laying eggs following hatching and mating, and the post-oviposition period refers to the number of days they survive after oviposition is terminated. The mean values of adult longevity, in both sexes, were compared through Student's $t$-test $(\mathrm{p}=0.05)$.

To evaluate fertility and the incubation period, eggs obtained randomly through cutting the filter paper containing eggs were used; these eggs were transferred to moist Petri plates and kept there up to the hatching of larvae. Besides these 25 eggs, the morphology and morphometry were used for these studies.

To evaluate parameters of larval phase, 127 just born larvae were individualized in $200 \mathrm{~mL}$ plastic containers and fed on ryegrass (Lolium multiflorum Lam.) which was changed daily up to the beginning of pre-pupal period, characterized by the interruption of feeding, size reduction, and a drop to the base of the container in search of substrate to metamorphose. During the change of feeding, head capsules were collected to measure and evaluate size and number of instars. Head capsules were measured under a stereomicroscope provided with an ocular micrometer with accuracy of a hundredth millimeter, and the correspondent measures of different larvae instars were grouped by distribution of frequency (Parra and Haddad, 1989) and the growing ratio was compared to the linear model suggested by Dyar (1890). Estimates of the duration of the larval period considered the time that larvae fed actively (called larval phase) up to the transformation into chrysalis, considered as the pre-pupae period (Parra, 1992). Correspondent percentages of survival were calculated.

Besides this, eight groups of 50 larvae, placed in glass cubes of $40 \times 40 \times 40 \mathrm{~cm}$ were fed on leaves of lettuce [Lactuca sativa Linn. - Asteraceae], soy [Glycine $\max ($ Linn.) Merril. - Fabaceae], tomato [Lycopersicum esculentum Mill. - Solanaceae], cabbage [Brassica oleracea Linn. var. capitata Linn. - Brassicaceae], birdseed [Phalaris canariensis Linn. - Poaceae], sugar cane [Saccharum officinarum Linn. - Poaceae], elephant-grass [Pennisetum purpureum (Pers.) Schum.], and wheat [Triticum aestivum Linn. - Poaceae] to evaluate behavior related to different host plants.

The pupae were placed in $14 \mathrm{~cm}$ diameter by $10 \mathrm{~cm}$ height plastic containers. Two days after metamorphose, the sex was identified (Butt and Cantu, 1962) and measures of length and width were taken using digital calipers with a precision of one hundredth of a millimeter; at the same time, the mass in semi-analytic scale was also measured with a precision of one percent of a gram. The Chi-square test $\left(\chi^{2}\right)(p=0.05)$ was used to test the hypothesis of equality of sex ratio; to evaluate differences between parameters of each sex, mean values were compared through Student's $t$-test $(\mathrm{p}=0.05)$. The percentage of survival was also evaluated.

From the values obtained, the biotic potential was calculated following the criteria referred to in Silveira Neto et al. (1976), diminishing the data of mortality and considering null resistance to environment.

Three adults of each sex and five caterpillars voucher specimens were deposited in the collection of the Museu de Ciências e Tecnologia da Pontifícia Universidade Católica do Rio Grande do Sul (PUCRS), reference number MCTP 15.369 and MCTP L702, respectively.

\section{Results and Discussion}

The complete life cycle was 86.54 days; average duration of each period of development is listed in Table 1 , and respective proportions illustrated in Figure 1.

The phases of egg, larva and pupa of A. mahalpa were rather longer than those referred to by Foester and Mello (1996) at $22{ }^{\circ} \mathrm{C}$ (egg: 6.0 days; larva and prepupae 27.4 days; and pupae; 20.5 days) which have to be assigned to Anicla ignicans (Guenée, 1852) as mentioned in Teston et al. (2001).

The mean duration of the adult phase was of 15.64 days for females (Figure 2a), and 14.73 for males (Figure 2b), and the difference between these values was not significant. The mean number of ovipositions per female was $7.36 \pm 0.20$, and each female laid an average of 2,014.21 $\pm 78.93 \mathrm{eggs}$, resulting in $273.67 \mathrm{eggs}$ per oviposition. These results are similar to those found 
Table 1. Mean duration and standard error in days and survival in percentage of development phases of the Anicla mahalpa reared at $20 \pm 2{ }^{\circ} \mathrm{C}$, UR $70 \% \pm 10 \%$ UR and 12 hours photophase.

\begin{tabular}{lrrc}
\hline \multicolumn{1}{c}{ Phases } & n & Mean & $\begin{array}{c}\text { Survival } \\
(\%)\end{array}$ \\
\hline Adult & 28 & $15.24 \pm 0.75$ & - \\
Male & 14 & $14.73 \pm 1.15$ & - \\
Female (total) & 14 & $15.64 \pm 1.00$ & - \\
Pre-oviposition & 14 & $5.29 \pm 0.32$ & - \\
Oviposition & 14 & $9.64 \pm 0.81$ & - \\
Post-oviposition & 14 & $0.71 \pm 0.27$ & - \\
Egg (incubate/laying) & 569 & $6.00 \pm 0.00$ & 97.24 \\
Larval & 109 & $36.47 \pm 0.44$ & 96.23 \\
Pre-pupal & 106 & $5.23 \pm 0.21$ & 97.25 \\
Pupal & 98 & $23.60 \pm 0.37$ & 92.45 \\
\hline
\end{tabular}

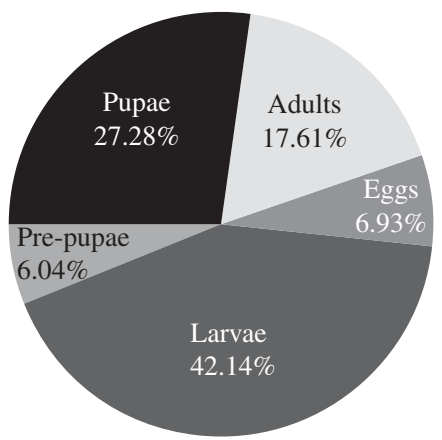

Figure 1. Percentage of development periods for Anicla mahalpa reared at $20 \pm 2{ }^{\circ} \mathrm{C}$, UR $70 \% \pm 10 \%$ UR and 12 hours photophase.

by Foester and Mello (1996) for A. ignicans reared at a temperature of $22{ }^{\circ} \mathrm{C}(1,807 \pm 513$ eggs and 227.6 eggs per oviposition), but they are different from those related by Teston et al. (2001) for $A$. infecta reared at $25^{\circ} \mathrm{C}$, the values of which were below the third part.

Eggs, as in many other Noctuidae (Peterson, 1964), were subspheric, with a diameter of $0.76 \pm 0.01 \mathrm{~mm}$ $(\mathrm{n}=25)$ and presented a high index of viability (Table 1).

The larvae of this species rest on the host plants (Figure 2c), similar of other Anicla species, in opposition of the most Noctuinae, characterized by underground habits (Teston et al. 2001). The larvae exhibeit variable colour patterns from green until dark brown (Figure $2 \mathrm{~d}$ ) as described for the A. infecta (Crumb, 1956). The coiled habit when disturbed similarly to the cutworms (Noctuinae) was present (Crumb, 1956; Holloway et al., 1992; Scoble, 1995).

Larvae (Figure 2a) passed trough six instars (Table 2) as observed in the other two species, at a mean ratio of growth of 1.482 which is within the expected if considering the model suggested by Dyar (1890). High viability during all the larval period, including the pre-pupae period (Table 1) is certainly related to the proper temperature under which this species was reared, as temperatures above
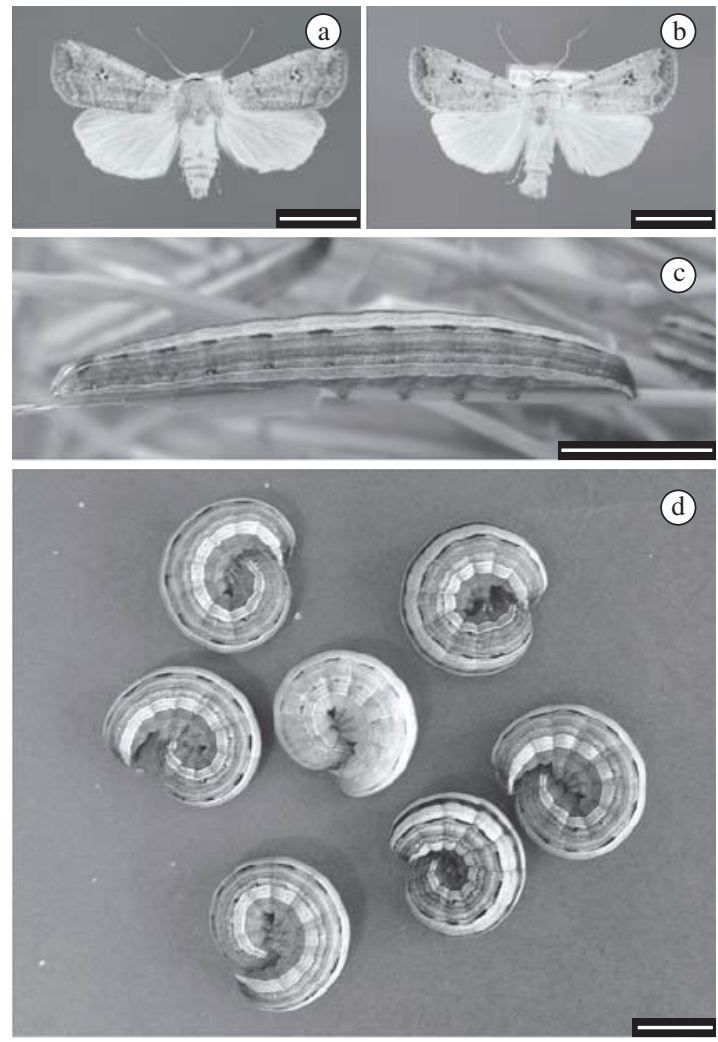

Figure 2. Anicla mahalpa: a) adult female; b) adult male; c) larvae resting in their host plant; and d) coiled larvae with different coloration (bars $=1 \mathrm{~cm}$ ).

Table 2. Mean and standard error in $\mathrm{mm}$ of cephalic capsules of Anicla mahalpa reared at $20 \pm 2{ }^{\circ} \mathrm{C}$, UR $70 \% \pm 10 \%$ UR and 12 hours photophase.

\begin{tabular}{cccc}
\hline Instar & n & Mean & Ratio of growth \\
\hline I & 87 & $0.467 \pm 0.002$ & - \\
II & 82 & $0.660 \pm 0.003$ & 1.413 \\
III & 79 & $0.995 \pm 0.008$ & 1.508 \\
IV & 78 & $1.407 \pm 0.014$ & 1.414 \\
V & 78 & $2.333 \pm 0.020$ & 1.658 \\
VI & 76 & $3.310 \pm 0.023$ & 1.419 \\
\hline
\end{tabular}

$25^{\circ} \mathrm{C}$ determined high mortality of both $A$. infecta (Teston et al., 2001) and A. ignicans (Foester and Mello, 1996).

No larvae that fed on lettuce leaves, soy, tomato or cabbage survived until the second instar, but the main part of those that fed on grasses (birdseed, 87,5\%; sugar cane, $88,6 \%$; elephant grass, $85,3 \%$; and wheat, $89,4 \%$ ) resulted in perfect adults. This indicates that, contrary to the $A$. infecta, which is a polyphytophagous (Biezanko and Bertholdi, 1951; Crumb, 1956; Silva et al., 1968; Biezanko et al., 1974), the A. mahalpa, like the A. ignicans (Silva et al., 1968; Biezanko et al., 1974; Foester and Mello, 1996), is an oligophytophagous, and feeds on native and cultivated grasses, especially in warmer regions. 
The obtecta pupae are reddish-brown, naked and smooth, similar to those of the A. infecta (Angulo and Olivares, 1997).

In the pupal phase, 51 females and 47 males were obtained, which does not go against the hypothesis of equality in sex ratio. The mean size and weight of pupae was not significantly different between genders; their mean values were $17.244 \pm 0.190 \mathrm{~mm}$ length; $6.069 \pm 0.064 \mathrm{~mm}$ width, and $0.331 \pm 0.008 \mathrm{~g}$ weight. The absence of significant differences between the pupae of different sexes was also observed in A. ignicans, reared at 18, 22 and $26{ }^{\circ} \mathrm{C}$ (Foester and Mello, 1996), in opposition to what was observed in the A. infecta (Teston et al., 2001).

Biotic potential calculated reached almost $1.5 \times 10^{13}$; this indicates that resistance to the environment, constituted by natural enemies and abiotic factors is preventing the A. mahalpa, found in Rio Grande do Sul for more than 50 years ago (Biezanko and Bertholdi, 1951), from reaching high population levels.

\section{References}

ANGULO, AO. and OLIVARES, TS., 1997. Anicla infecta (Ochsenheimer, 1816): pupa, larva y nuevo registro (Lepidoptera, Noctuidae). Bol. Soc. Biol. Concepción, vol. 68, p. 47-52.

BIEZANKO, CM. and BERTHOLDI, RE., 1951. Principais noctuídeos prejudiciais às plantas cultivadas em arredores de Pelotas. Agronomia, vol. 10, no. 4, p. 235-247.

BIEZANKO, CM., RUFFINELLI, A. and LINK, D., 1974. Plantas y otras sustancias alimenticias de las orugas de los lepidopteros uruguayos. Rev. Centro Ciências Rurais, vol. 4, no. 2, p. 107-148.

BUTT, BA. and CANTU, E., 1962. Sex determination of lepidopterous pupae. Washington: USDA. 7 p.

CRUMB, SE., 1956. The larvae of the Phalaenidae. Technical Bulletin n. 1135. Washington: USDA. 356 p.
DYAR, HG., 1890. The number of molts of lepidopterous larvae. Psyche, vol. 5, no. 175-176, p. 420-422.

FOERSTER, LA. and MELLO, MEF., 1996. Desenvolvimento e sobrevivência de Anicla infecta Guenée (Lepidoptera: Noctuidae) em diferentes temperaturas. Anais Soc. Entomol. Brasil, vol. 25, no. 1, p. 33-38.

HAMPSON, GF., 1903. Catalogue of the Lepidoptera Phalaenae in the British Museum. vol. 4. London: Taylor and Francis. 689 p.

HEPPNER, JB., 1991. Faunal regions and the diversity of Lepidoptera. Trop. Lepidoptera, vol. 2, suppl. 1, p. 1-85.

HOLLOWAY, JD., BRADLEY, JD. and CARTER, DJ., 1992. Lepidoptera. In BETTS, CR. (ed.), IIE Guides to Insects of Importance to Man. vol. 1. Wallingford: CAB International. $263 \mathrm{p}$.

PARRA, JRP., 1992. Técnicas de criação de insetos para programas de controle biológico. Piracicaba: FEALQ. 161 p.

PARRA, JRP. and HADDAD, M. de L., 1989. Determinação do Número de Ínstares de Insetos. Piracicaba: FEALQ. 49 p.

PETERSON, A., 1964. Egg types among moths of the Noctuidae (Lepidoptera). The Florida Entomologist, vol. 47, no. 2, p. 71-91.

POOLE, RW., 1989. Noctuidae. In HEPPNER, JB. (ed.), Lepidopterorum Catalogus. New York: Brill. 1314 p.

SCOBLE, MJ., 1995. The Lepidoptera: form, function and diversity. New York: Oxford University Press. 404 p.

SILVA, AGA., GONÇALVES, CR., GALVÃO, DM., GONÇALVES, AJL., GOMES, J., SILVA, NM. and SIMONI, L., 1968. Quarto catálogo dos insetos que vivem nas plantas do Brasil, seus parasitos e predadores. Parte 2, Tomo 1. Min. Agricultura, Rio de Janeiro. 622 p.

SILVEIRA NETO, S., NAKANO, O., BARDIN, D., VILLA-NOVA, NA., 1976. Manual de ecologia de insetos. São Paulo: Ceres. 420 p.

TESTON, JA., SPECHT, A. and CORSEUIL, E., 2001. Biology of Anicla infecta (Ochsenheimer, 1816) (Lepidoptera, Noctuidae, Noctuinae), under laboratory condictions. Braz. J. Biol. $=$ Rev. Bras. Biol., vol. 61, no. 4, p. 661-666. 